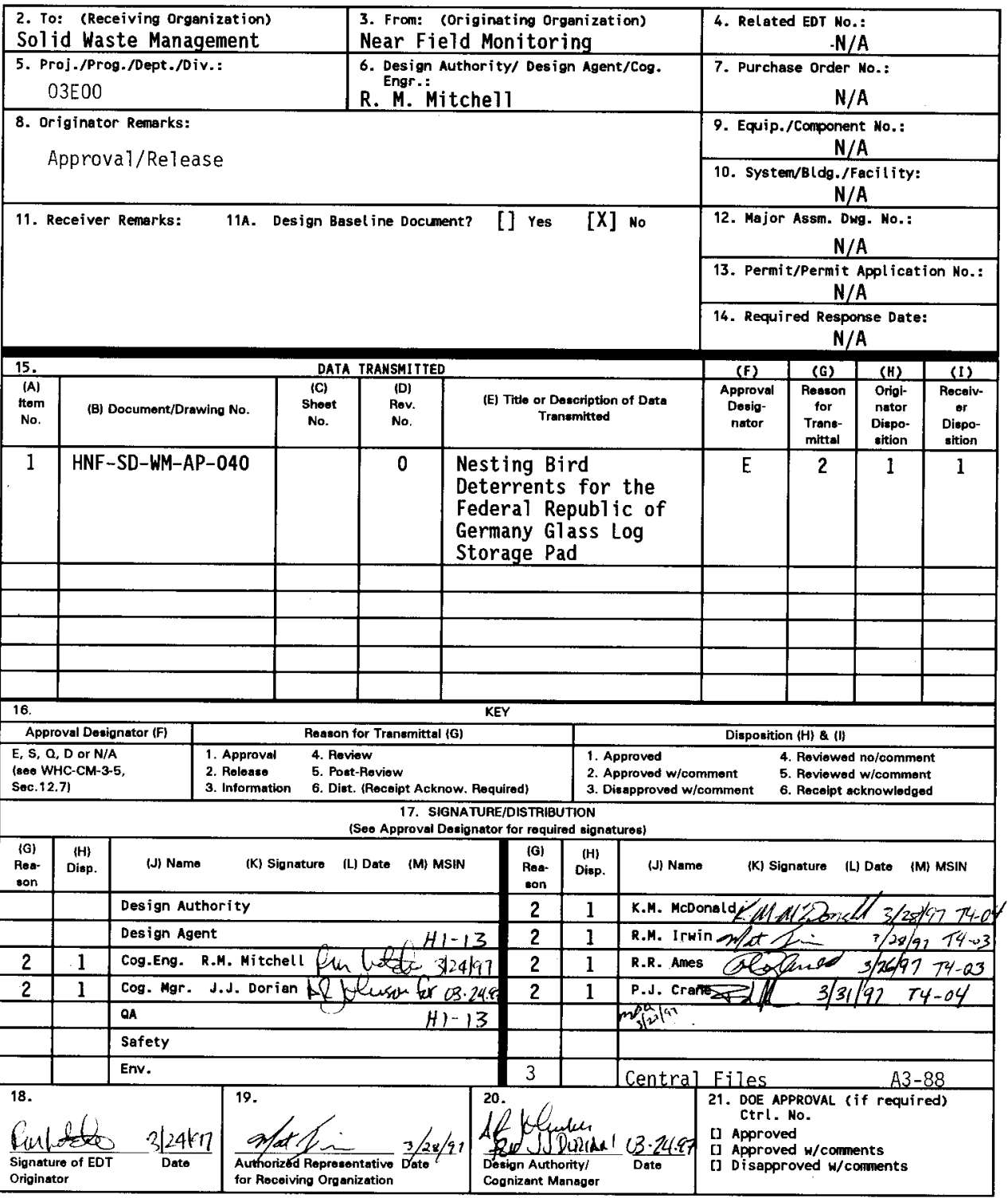




\section{NESTING BIRD DETERRENTS FOR THE FEDERAL REPUBLIC OF GERMANY GLASS LOG STORAGE PAD}

R. M. Nitchel1, A. R. Johnson

Rust Federal Services Inc. Northwest Operations, Richland, WA 99352

U.S. Department of Energy Contract DE-ACO6-96RL13200

EDT/ECN: 620479

Org Code : 0 OE300 03E00

B\&R Code: 820201000
UC: 2000

Charge Code: POFK15

Total Pages: 11

Key Words: Birds, Deterrents, Federal Republic of Germany, Solid Waste Operations Complex

Abstract: This document provides description and scope of effort to provide deterrents to migratory bird nesting in the proposed site for the Federal Republic of Germany (FRG) Glass Log Storage Pad.

TRADEMARK DISCLAIMER. Reference herein to any specific comercial product, process, or service by trade name, trademark, manufacturer, or otherwise, does not necessarily constitute or imply its endorsement, recommendation, or favoring by the United States Government or any agency thereof or its contractors or subcontractors.

Printed in the United States of America. To obtain copies of this document, contact: Document Control Services, P.0. BOX 950, Mailstop H6-08, Richland WA 99352, Phone (509) 372-2420; Fax (509) 376-4989.

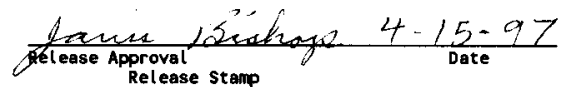
Release Stamp

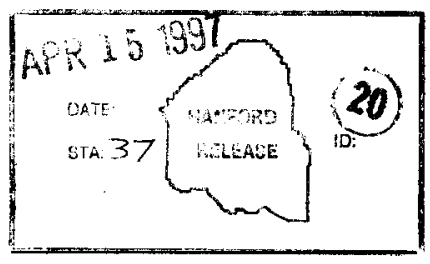


HNF-SD-WM-AP-040, Rev. 0

\section{CONTENTS}

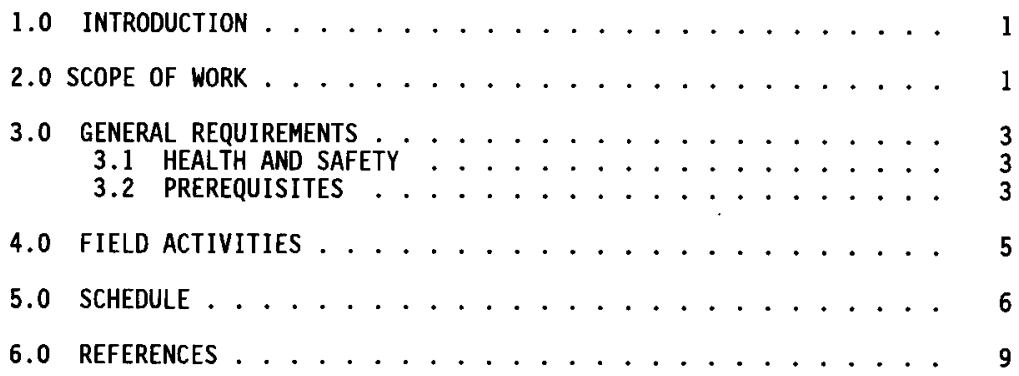

\section{FIGURES}

Figure 1. Map of 200 West Showing Location of the Proposed Storage Pad ................ 2

Figure 2. Digital Photograph of Exclusion Zone Looking from Southwest Corner............ 4

Figure 3. Map of Exclusion Zone Showing Stake Locations and Proposed Walking Transects.......... 7

Figure 4. Configuration for Staking Prime Nesting Locations . . . 8 


\subsection{INTRODUCTION}

A proposed storage pad will be constructed in the 200 West Area for the storage of isotopic heat and radiation sources from the Federal Republic of Germany. The pad will be constructed in the southern portion of the Solid Waste Operations Complex near the existing Sodium Storage Pad (Figure 1).

Following a biological review by Pacific Northwest National Laboratory (PNNL) personnel (Brandt 1996), it was determined that in order for construction to take place after March 15, 1997, actions would need to be taken to prevent migratory birds from nesting in the project area. Special attention was focused on preventing sage sparrows and loggerhead shrikes, both Hanford Site species of concern (DOE/RL 1996), from nesting in the area. This activity plan details the methods and procedures that will be used to implement these nesting deterrents.

\subsection{SCOPE OF WORK}

The objective of the task is to provide nonharmful physical deterrents to migratory bird nesting activity in the proposed project area (Figure 1). This has resulted in the delineation of an exclusion zone measuring approximately $38 \mathrm{~m} \times 125 \mathrm{~m}$ as indicated on the map in Figure 1 . The actual construction site, measuring approximately $10 \mathrm{~m} \times 40 \mathrm{~m}$ will be located within the boundaries of the exclusion zone. The effect of this effort is that nesting birds will be relocated from an area which does not comprise prime habitat (one boundary is along a road and another proximal to an existing storage pad) into areas east and west of the site which represent good habitat. It is not expected that this effort would result in harm to any birds or prevent any pairs from nesting elsewhere. These deterrents will only be in place during the 1997 nesting season. 


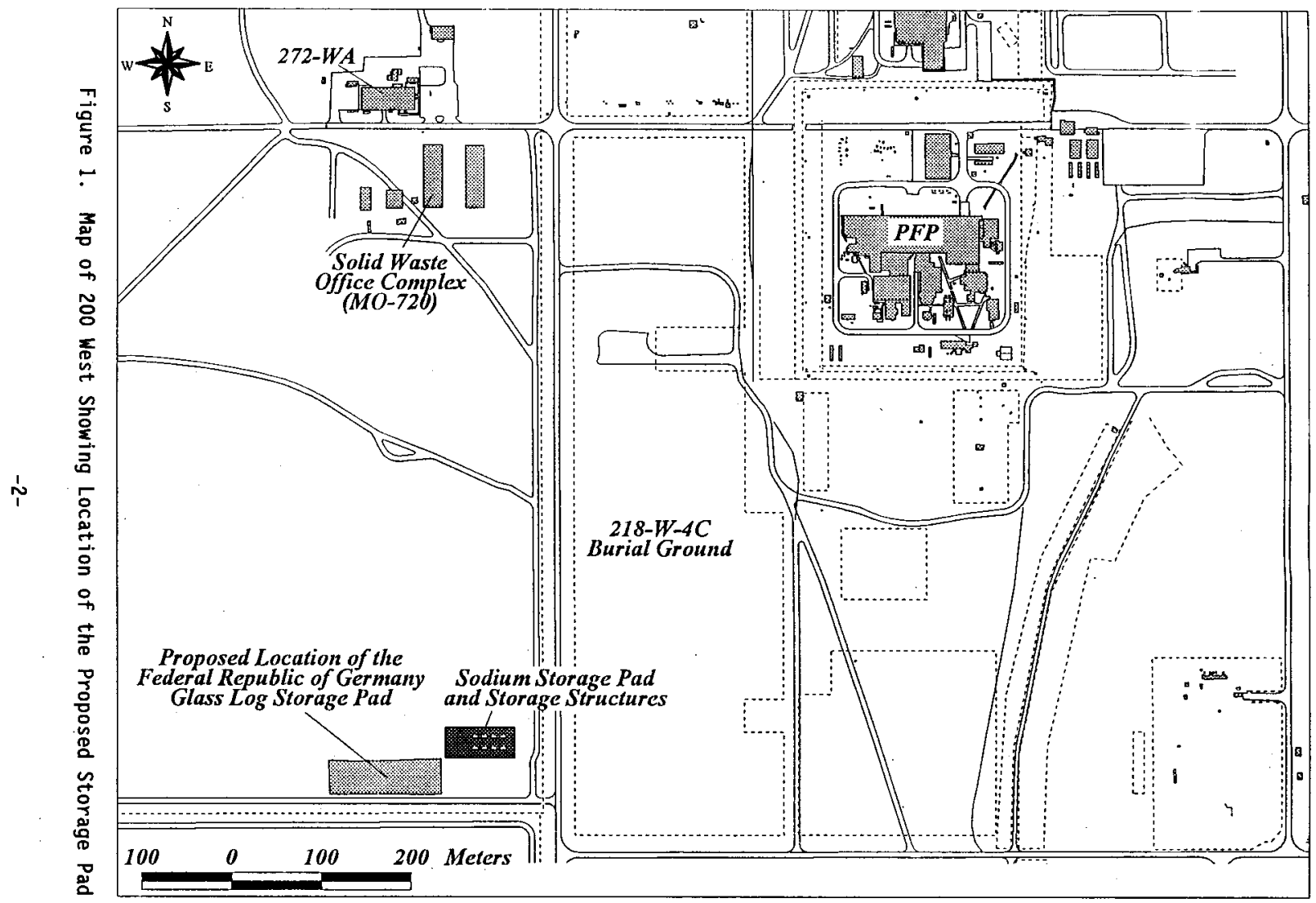


HNF-SD-WM-AP-040, Rev. 0

\subsection{GENERAL REQUIREMENTS}

Tasks associated with this activity will be conducted by Rust

Federal Services Northwest (RFSNW) personnel with assistance provided by Waste Management personnel. Tasks will be conducted in accordance with the following methods and guidelines:

- Environmental Investigations and Site Characterization Manual, WHC-CM-7-7 (WHC 1988a)

- Environmental Compliance Manual, WHC-CM-7-5 (WHC 1988b)

- Radiological Control Practices and Procedures Manual, WHC-CM-4-27-6 (WHC 1993)

- Safety Manual, WHC-CM-1-10 (WHC 1987)

- Operational Environmental Monitoring, WHC-CM-7-4 (WHC 1996)

\subsection{HEALTH AND SAFETY}

Job and site-specific activities will be guided by normal field operating procedures. The proposed site does not pose any chemical or radiological hazards to field workers. Potential safety hazards associated with field activities should be noted: slips/trips and falls, adequate footwear, biological hazards such as snakes, spiders, scorpions, etc. Those involved with driving stakes should wear gloves and be aware of pinch-points. A tail-gate safety meeting will be held with personnel who will be involved in deterrent set-up or other activities to acquaint them with potential job hazards.

\subsection{PREREQUISITES}

The following tasks were completed prior to initiation of any deterrent efforts and construction activities:

- Biological Resources Review (Brandt 1996)

- Cultural Resources Review (Cadoret 1997) 
HNF-SD-WM-AP-040, Rev. 0

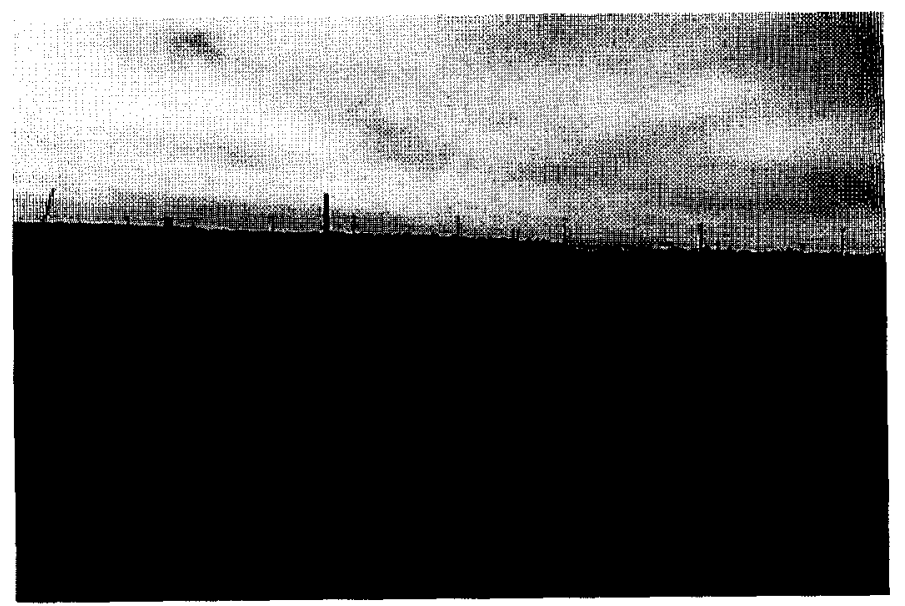

Figure 2. Digital Photograph of Exclusion Zone Looking From Southwest Corner 


\subsection{FIELD ACTIVITIES}

The proposed construction site consists largely of a tract of native big sagebrush (Artemisia tridentata) and Sanberg's bluegrass (Poa sandbergi $i$ ) which over the years has been disturbed by various waste management activities, such as roads, buildings, and storage sites (See Figure 1). The exclusion site consists of an area measuring approximately $38 \mathrm{~m}$ by $125 \mathrm{~m}$ bordered by a dirt road and fence on the southern boundary (Figure 1). Figure 2 is a digital photograph looking at the site from the southeast corner along the road. The Sodium Storage Pad Structures can be seen in the right center of the photo.

The deterrent activities will take place in two phases. For the first phase, site personnel will visit the site regularly, walking transects into the designated habitat establishing human presence which will act as a deterrent to birds establishing nests. The transects should be perpendicular to the road, run approximately every 20 meters for a total of seven transects to complete the site (Figure 3). The transects should be walked midway between the metal stakes described below. This should be done early in the day. This effort should be continued until construction activities actualiy begin. Personnel involved should be instructed that none of the animals on the site are to be physically or forcibly removed; this activity is a deterrent only.

A second phase which will be implemented for deterring nesting birds will involve the use of reflective "scare" tape. This method has proven to be an effective deterrent for keeping birds out of orchards (Bruggers et al. 1986, Dolbeer et al. 1986). It has been used locally with good results in keeping sparrows, blackbirds, crows, etc., from eating fruit crops. It should prove even more effective at preventing non-intrusive native birds from establishing nesting sites.

Metal stakes will be located within the exclusion zone on 20 meter centers. Due to the relatively poorer habitat and disturbance near the road on the southern boundary, the first line of stakes will be located approximately 9 meters from the non-vegetated road edge. The layout is provided in Figure 3. A total of 16 stakes will be needed to adequately cover the exclusion zone. Following placement of the stakes, rope will be stretched between each stake along the north/south axis. Reflective tape will then be placed along the rope at 2 to 3 foot intervals.

Additionally, areas which appear to constitute prime nesting locations will be located and possibly receive a secondary deterrent. These areas will be circumscribed with three stakes forming a triangle. Twine or rope will be used to connect the stakes and the reflective tape will be tied along the rope to enhance the deterrent effect. The configuration for this effort is shown in Figure 4. 


$$
\text { HNF-SD-WM-AP-040, Rev. } 0
$$

Periodic visits to the site will ensure that any missing reflective tape or downed rope will be replaced or repositioned as necessary. The stakes and tape will be left in place until construction is initiated and will then be removed.

\subsection{SCHEDULE}

The Biological Resources Review and Cultural Resources Review for the proposed storage site have previously been completed. The exclusion site has been visited by RFSNW biologists for a site reconnaissance and was surveyed with the Geographic Positioning System (GPS) on March 6 , 1997. Walk-thru by site personnel will be initiated on March 13, 1997. Emplacement of the stakes and reflective tape will be started on March 13, 1997. These efforts will remain in effect until construction is initiated, or we are otherwise notified by Waste Management personnel. 


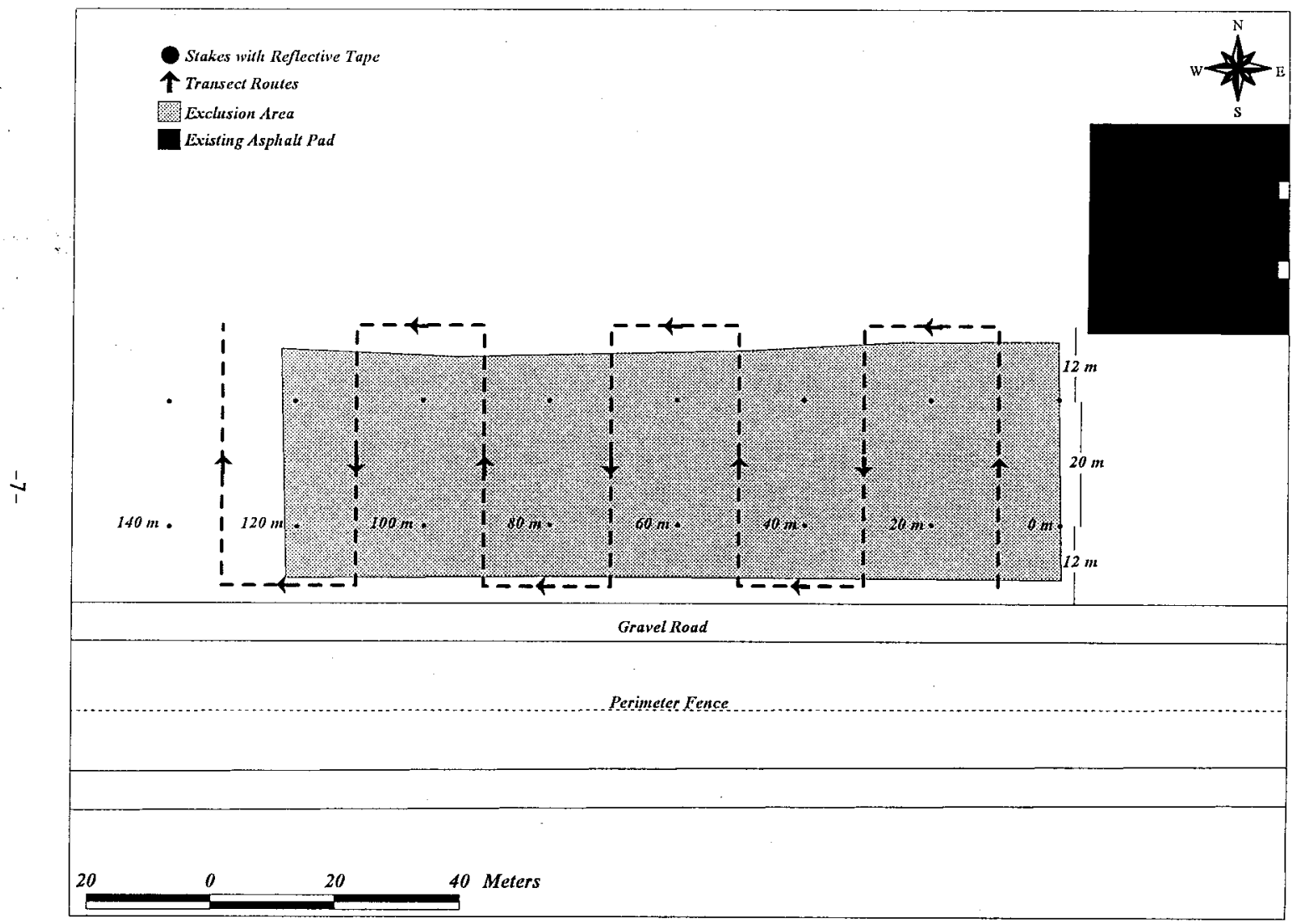

Figure 3. Map of Exclusion Zone Showing Stake Locations and Proposed Walking Transects 


$$
\text { HNF-SD-WM-AP-040, Rev. } 0
$$

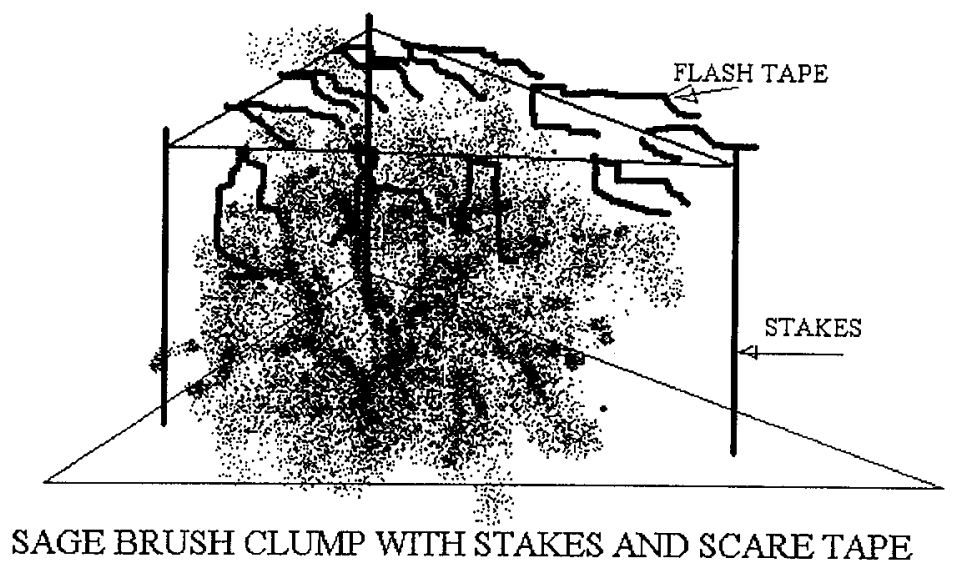

Figure 4. Configuration for Staking Prime Nesting Locations 


\subsection{REFERENCES}

Brandt, C. A., 1996, Biological Review of the FRG Sealed Isotopic Heat Sources Project, 200 West Area, 97-200-009, PNNL, Richland, Washington.

Brugger, R. L., J. E. Brooks, R. A. Dolbeer, P. P. Woronezki, R. K. Pandit, T. Tariveo, and M. Hoque, 1986, "Responses of Pest Birds to Reflecting Tape in Agriculture, "Wildlife Society Bulletin 14:161-170.

Cadoret, N. A., 1997, Cultural Resources Review of the FRG Sealed Isotopic Heat Sources Project, HCRC 97-300-009, PNNL, Richland, Washington.

$\mathrm{DOE} / \mathrm{RL}, 1996$, Hanford Site Biological Resources Management Plan, DOE/RL 96-32, Richland, Washington.

Dolbeer, R. A., P. P. Woronezki, and R. L. Bruggers, 1986, "Reflecting Tapes Repel Blackbirds from Millet, Sunflowers and Sweet Corn," Wildlife Society Bulletin 14:418-425.

WHC, 1987, Safety Manual, WHC-CM-1-10, 3 Vols., Westinghouse Hanford Company, Richland, Washington.

WHC, 1988, Environmental Compliance Manual, WHC-CM-7-7, Westinghouse Hanford Company, Richland, Washington.

WHC, 1988, Environmental Investigations and Site Characterization Manua 7, WHC-CM-7-7, Westinghouse Hanford Company, Richland, Washington.

WHC, 1993, Radiological Control Practices and Procedures Manual, WHC-CM-4-27, Westinghouse Hanford Company, Richland, Washington.

WHC, 1996, Operational Environmental Monitoring, WHC-CM-7-4, Westinghouse Hanford Company, Richland, Washington. 


\begin{tabular}{|c|c|c|c|c|c|}
\hline \multicolumn{6}{|c|}{ DISTRIBUTION SHEET } \\
\hline \multirow{2}{*}{$\begin{array}{l}\text { To } \\
\text { R. M. Irwin }\end{array}$} & \multirow{2}{*}{\multicolumn{3}{|c|}{$\begin{array}{l}\text { From } \\
\text { R. M. Mitchel1 }\end{array}$}} & \multicolumn{2}{|c|}{ Page 1 of 1} \\
\hline & & & & \multicolumn{2}{|c|}{ Date April 7, 1997} \\
\hline \multirow{2}{*}{\multicolumn{4}{|c|}{$\begin{array}{l}\text { Project Title/Work Order } \\
\text { Nesting Bird Deterrent/POFK15 }\end{array}$}} & \multicolumn{2}{|c|}{ EDT No. 620479} \\
\hline & & & & \multicolumn{2}{|c|}{ ECN No. } \\
\hline Name & MSIN & $\begin{array}{c}\text { Text } \\
\text { With All } \\
\text { Attach. }\end{array}$ & Text Only & $\begin{array}{l}\text { Attach./ } \\
\text { Appendix } \\
\text { Only }\end{array}$ & $\begin{array}{l}\text { EDT/ECN } \\
\text { Only }\end{array}$ \\
\hline R. R. Ames & T4-03 & $x$ & & & \\
\hline P. K. Brockman & $\mathrm{H} 1-11$ & $x$ & & & \\
\hline P. J. Crane & T4-04 & $\mathrm{X}$ & & & \\
\hline J. J. Dorian & $\mathrm{H} 1-13$ & $x$ & & & \\
\hline R. M. Irwin (3) & T4-03 & $x$ & & & \\
\hline A. R. Johnson (3) & $\mathrm{H} 1-13$ & $x$ & & & \\
\hline K. M. McDonald & T4-04 & $x$ & & & \\
\hline I. L. Metcalf & L6-26 & $x$ & & & \\
\hline R. M. Mitchell (6) & $H 1-13$ & $x$ & & & \\
\hline K. E. Schwartz & L6-26 & $x$ & & & \\
\hline Central Files & $A 3-88$ & $x$ & & & \\
\hline
\end{tabular}

